\title{
Universal Molecular Fixative
}

National Cancer Institute

\section{Source}

National Cancer Institute. Universal Molecular Fixative. NCI Thesaurus. Code C63346.

A methanol/polyethylene glycol-based fixative that is useful for preservation of DNA, RNA, and proteins. It is particularly useful for preservation of nucleic acids in situ. 